\title{
An Assessment of Factors That Affect Students Speaking Skill The Case of First Year English Major Students at Debre Markos University
}

\author{
ASNAKE TESHAGER YIMAM
}

\begin{abstract}
This study was carried out to assess on the factors that affect students speaking skill. There are many problems have to affect students speaking skill like: lack of vocabulary, lack of pronunciation and mother tongue influence. The major objective of this study was to assess factors that affect students speaking skill. The case of first year English major students at Debre Markos University. The researcher used all first year English major students. Therefore, the researcher used comprehensive methods since the number of students. The studies were gathered through observation and questionnaires. The collected data were analyzed by using both quantitative and qualitative methods. The finding of the study showed that students did not communicate by English language because they have shyness, lack of vocabulary and lack of interest. were the factors that affect students speaking skill. The finally conclusion, this study has tried to find out the major factors affect students speaking skill. And the recommendation of this study students should practice way of pronouncing words through different techniques like, listening English language media, using dictionary to know the exact sound of the word.
\end{abstract}

DOI: $10.7176 / \mathrm{RHSS} / 9-17-01$

Publication date:September $30^{\text {th }} 2019$

\subsection{Back ground of the study}

Different scholars define language in different ways. According to Singh [2007] language is a system of human communication that uses arbitrary signals like voice, sounds, gesture, or written symbols. It is the most significant possession of human being communication in conveying and sharing idea, feeling, emotion and information both in spoken and written forms. There are four language skills. listening, reading, writing, and speaking skill. Among the four skills. Speaking is the action of passing information or expressing our thought and feeling in spoken language. The term is also used in reference to the process of delivering speech. As to Joyce [1997] speaking is an interactive process of constructing meaning that involves producing, receiving and processing information. It is form and meaning are dependent on text. Including the participants experience, the physical environment and the purpose for speaking. it is often spontaneous, open ended and evolving. Speaking requires that learners not only know how to produce specific points of language like grammar, pronunciation or vocabulary, but the understand when, why and structure and conventions are different from written language cohen [1996]many other researches also point out problem of fluency and accuracy in speaking. Regarding to this some scholars give their opinion, like khan [1998]who suggest that good language learners employ a variety of strategies to improve their communication ability. And speaking strategies are one of the most important aspects in dealing with communication skill as they enhance learners. confidence and fluency. However there are some factors at speaking which first year students try speaking English language.

\subsection{Statement of the problem}

The problem was to be more serious on case of speaking skill. Almost majority of students frequently use their mother tongue both in the class and out of the class. Because, many students are not speak English language perfectly in the class and out of the class. Due to the lack of vocabulary, lack of confidence and lack of grammar usage. The problem is not only contributed to the side of learner but also other reasons. These includes: the criteria, formality ,and methods used in designing the context of learning materials. so the students should develop their speaking skill during classroom discussion and presentation to be effective in their academic career. Even though there is a problem of speaking skill in all level, first year English major students have great difficulty of speaking skill. Since they have no experience in speaking at high school and preparatory school as. I have observed the classroom during speaking session. Therefore, the researcher decided to find out the problems that affect the speaking skill of first year English major students at Debre markos university. To this end researcher conducted the research concerning the problem of speaking English so as to provide solution.

\section{Research question}

1. What are the major problem that hinder students speaking skill?

2. What is the attitude of students towards speaking skill?

3. What are the possible solutions to tackle the problem? 


\section{RESEARCH DESIGN AND METHODOLOGY}

The main objective of this study is to assess the factors that affect speaking skill of forst year English language and literature students at Debre Markos University. Therefore, this chapter discuss the research design, subject of the study, population of the study, sampling tachniques, data collection instrument and techniques of data analysis was conduct the study in accordance with objective state above

\subsection{Research of design}

In this study, the researcher used descriptive method of research design.

The researcher used quantitative and qualitative methods of the research design. The quantitative data were presented with tables in percentage and qualitative data were presented interview and class observation. Whereas the data collated through sampling techniques, subject of the study, data collection instruments and methods of data analysis.

\subsection{Subject of the study}

The target population of the study were all first year English major students at Debre Markos university .It was also focused one instructor out of the 35 instructors of English language and literature department

\subsection{Sampling techniques}

The researcher used both comprehensive and purpose sampling techniques. Comprehensive techniques was used to collect information from the total number of 31 students by distributing questionnaire, because their number was manageable and it helps to collect(get) necessary information from the a number of respondents. And the purposive techniques were used to select one instructor for the purpose of interview who teach first year English major students advanced speaking course.

\section{3 data collection instruments}

To gather or adequate data for successful accomplishment of the study, the researcher used questionnaire, interview and classroom observation for her study.

\subsubsection{Questionnaires}

The aim of questionnaire was to collect relevant information from students. This questionnaire was distributed for 31 students with provide both closed ended and open ended option. The main intention of closed ended questionnaire is to get specific data in the short time while open-ended is to get general data for the study from each individual's point of view. Also it prepared by thinking it could have an advantage for researcher to get unexpected (hindered) ideas that would contribute to the study, if they done in a well manner. In this study the questionnaire would focused only on students. It was consists of (10) close ended and (3) open-ended questions. During the questionnaire, students were responded questions about factor that affect students' speaking skill.

\subsubsection{Interview}

Some other data have been gathered through the interview .In this study the interview only questionnaire only focused on instructor who teach first year English major students speaking skill. The main objective of interview was to get additional information from the teacher. So the researcher developed structured interview why, because the researcher need from the respondents facts and good information for the study. The researcher was prepared three interview questions of the selected instructor from the department of English language and literature instructor

\subsubsection{Class room observation}

The researcher observed the students ability in speaking to identify the problems in the actual technique learning process. This type of instrument was to get more reliable information than others. The researcher used observation to check the existing situation in the class. During classroom observation, the researcher observed how much students are willing to deliver speech in the class

\subsection{Data collection procedure}

The researcher was distributed questionnaire to selected respondents and would collect back after it was distributed by them. In the study the questionnaire focused only on the students while interview was istructor. During interview, the researcher was prepared question in the form of short note from the respondent's point of view. Finally, the researcher was carried out classroom observation based on observed the major factors that affect students speaking skill.

\subsection{Methods of data analysis}

After collecting the data, the researcher used mixed type of data analysis methods that are both quantitative and qualitative methods of data analysis based on the type of questions designed. The data obtained from students through questionnaire were analyzed and tabulated quantitatively using frequency and percentage. While 
information`s that collected through interview and observation were used to analyze qualitative method of analysis.

DATA ANALYSIS AND INTERPRETATION

In this chapter the researcher analyzed and interpreted the data which was collected through questionnaires and observation. The data analyzed and interpreted as follows.

4.1 Analysis of students close ended questions .

Table 1:the students response whether major problem to affect your speaking skill or not.

\begin{tabular}{|l|l|l|l|l|}
\hline \multirow{2}{*}{ NO } & Item & Variables & $\begin{array}{l}\text { Number of } \\
\text { response }\end{array}$ & $\begin{array}{l}\text { percentage } \\
\%\end{array}$ \\
\hline \multirow{2}{*}{1} & \multirow{2}{*}{$\begin{array}{l}\text { What is the major problem to } \\
\text { affect your speaking skill? }\end{array}$} & Lack of pronunciation & 11 & $35.48 \%$ \\
\cline { 3 - 6 } & & Mother tongue influence & 10 & $32.25 \%$ \\
\cline { 3 - 6 } & Lack of confidence & 7 & $22.58 \%$ \\
\cline { 3 - 6 } & & Lack of motivation & 3 & $9.67 \%$ \\
\hline \multirow{2}{*}{ Total } & & & 31 & $100 \%$ \\
\hline
\end{tabular}

As shown in the above table 11(3548\%) , and 10(32.25\%) respondents answered that they lack of pronunciation and mother tongue influence respectively. According to the students response major problem to affect their speaking skill, but 7(22.58\%),3(9.67\%) respondents answered lack of confidence and lack of motivation respectively. Because of major problem to affect their speaking skill. This indicated that majority of students have lack of pronunciation and mother tongue influence problem.

Table 2: students response whether what kind of hinder they faced speaking skill?

\begin{tabular}{|l|l|l|l|l|}
\hline \multirow{2}{*}{2} & Item & variables & Number of respons & percentage(\%) \\
\hline \multirow{2}{*}{$\begin{array}{l}\text { What kind of hinder your } \\
\text { faced in speaking skill? }\end{array}$} & Lack of confidence & 5 & $16.12 \%$ \\
\cline { 3 - 5 } & & Lack of vocabulary & 8 & $25.81 \%$ \\
\cline { 3 - 5 } & & Lack of motivation & 10 & $33.3 \%$ \\
\cline { 3 - 5 } & & Lack of pronunciation & 8 & $25.81 \%$ \\
\hline Total & & & 31 & $100 \%$ \\
\hline
\end{tabular}

The above table depicts that 5(16.12\%), 8(25.81\%) respondents answered that lack of confidence and lack of vocabulary, because lack of accurate confidence affects their speaking skill. But 10(33.3\%), 8(25.81\%) respondents answered lack of motivation and lack of pronunciation respectively. As the data shoes, majority of the students have lack of motivation and lack of vocabulary problem

Table 3:the students response whether how often the lack of appropriate English pronunciation affects their speaking skill.

\begin{tabular}{|c|c|c|c|c|}
\hline No & Item & variables & $\begin{array}{l}\text { Number of } \\
\text { response }\end{array}$ & percentage $(\%)$ \\
\hline \multirow[t]{4}{*}{3} & \multirow{4}{*}{$\begin{array}{l}\text { How often the lack of } \\
\text { appropriate English } \\
\text { pronunciation affects your } \\
\text { speaking skill. }\end{array}$} & Always & 9 & $29 . .03 \%$ \\
\hline & & Rarely & 6 & $19.35 \%$ \\
\hline & & Sometimes & 14 & $45.16 \%$ \\
\hline & & Not all & 2 & $6.45 \%$ \\
\hline Total & & & 31 & $100 \%$ \\
\hline
\end{tabular}

As can it be seen from the above table, 9(29.03\%), 6(19.35\%) respondent answered always and rarely 
respectively. Because lack of appropriate English pronunciation affects their speaking skill. Whereas 14(45.16\%), $2(6.45 \%)$ of respondents answered that sometimes. Because lack of appropriate English pronunciation affects when they speak. In the class, most of students do not have lack of appropriate English pronunciation affects when they speak

Table 4:the students response whether lack of enough English vocabulary affect their speaking or not.

\begin{tabular}{|c|c|c|c|c|}
\hline No & Item & Variables & $\begin{array}{l}\text { Number of } \\
\text { response }\end{array}$ & percentage $(\%)$ \\
\hline \multirow[t]{4}{*}{4} & \multirow{4}{*}{$\begin{array}{l}\text { Lack of enough English } \\
\text { vocabulary affects my speaking } \\
\text { skill. }\end{array}$} & Strongly agree & 10 & $32.25 \%$ \\
\hline & & Agree & 8 & $25.81 \%$ \\
\hline & & Disagree & 6 & $19.35 \%$ \\
\hline & & Strongly disagree & 7 & $22.58 \%$ \\
\hline Total & & & 31 & $100 \%$ \\
\hline
\end{tabular}

As it is shown in the above table $10(32.25 \%)$, and $8(25.81 \%)$ respondents answered that they strongly agree and agree respectively. According to the students response, lack of enough vocabulary affects their speaking skill. but $6(19.35 \%), 7(22.58 \%)$ of respondents answered disagree and strongly disagree respectively. Because of lack of enough English vocabulary does not affect their speaking skill. This indicated that majority of students have lack of enough vocabulary problem.

Table 5:students response which of the following is affects their speaking ability?

\begin{tabular}{|c|c|c|c|c|}
\hline No & Item & Variables & $\begin{array}{l}\text { Numbers of } \\
\text { response }\end{array}$ & percentage $(\%)$ \\
\hline \multirow[t]{4}{*}{5} & \multirow{4}{*}{$\begin{array}{l}\text { Which of the following affects } \\
\text { your speaking ability. }\end{array}$} & Lack of pronunciation & 3 & $9.67 \%$ \\
\hline & & Mother tongue influence & 9 & $29.03 \%$ \\
\hline & & Lack of vocabulary & 5 & $16.12 \%$ \\
\hline & & Lack of experience & 14 & $45.16 \%$ \\
\hline Total & & & 31 & $100 \%$ \\
\hline
\end{tabular}

As table indicated,3(9.67.\%),9(29.03\%) of respondents responded that lack of pronunciation and lack of mother tongue influence respectively. As affects their speaking ability.But,5(16.12\%). 14.(45.16\%) of respondents responded that lack of vocabulary and lack of experience respectively. According to the respondents that lack of vocabulary and lack of experience does not affect their speaking ability.

Table 6:students response which one of the negative attitude towards English affects their speaking ability?

\begin{tabular}{|l|l|l|l|l|}
\hline \multirow{2}{*}{ No } & Item & Variables & Numbers of response & percentage $(\%$ \\
\hline \multirow{2}{*}{6} & $\begin{array}{l}\text { Which one affects your } \\
\text { speaking ability? }\end{array}$ & Shyness & 16 & $51.61(\%)$ \\
\cline { 3 - 5 } & & Lack of confidence & 10 & $32.35 \%$ \\
\cline { 3 - 5 } & & Lack of vocabulary & 3 & $9.67 \%$ \\
\cline { 3 - 5 } & & Lack of motivation & 2 & $6.45 \%$ \\
\hline Total & & & 31 & $100 \%$ \\
\hline
\end{tabular}

As table 6 indicated, 16(51.61\%), 10(32.35\%) of respondents responded that shyness and lack of confidence respectively as the negative attitude English affects speaking ability. But 3(9.67\%), 2(6.45\%) of respondents responded that lack of vocabulary and lack of motivation respectively. According to the respondents that the negative attitude towards English affects speaking ability. This indicates that majority of the students have shyness and lack of confidence. 
Tabel 7:the students response on whether lack of immediate feedback from the teachers.

\begin{tabular}{|l|l|l|l|l|}
\hline \multirow{2}{*}{ No } & Item & Variable & $\begin{array}{l}\text { Number of } \\
\text { response }\end{array}$ & percentage $(\%)$ \\
\hline \multirow{3}{*}{7} & $\begin{array}{l}\text { Lack of immediate feedback from } \\
\text { the instructor. }\end{array}$ & Agree & 10 & $32.25 \%$ \\
\cline { 3 - 5 } & & strongly agree & 13 & $43.33 \%$ \\
\cline { 3 - 5 } & & Strongly disagree & 3 & $9.67 \%$ \\
\cline { 3 - 5 } & & Disagree & 5 & $16.12 \%$ \\
\hline \multirow{2}{*}{ Total } & & & 31 & $100 \%$ \\
\hline
\end{tabular}

As table 7 indicated, 10(32.25\%), 13(43.33\%) of respondents answered that agree and strongly disagree respectively. According to the students response, lack of immediate feedback from the teachers, but 3(9.67.\%),5(16.12.\%) respondents answered strongly disagree and disagree respectively. Because of immediate feedback from the teacher does not affect their speaking skill. This indicates that majority of the students have lack of immediate feedback from the teachers problem to develop their speaking skill.

Table 8:the students response how often do the teachers correct their mistake while you are speaking skill your tasks?

\begin{tabular}{|c|c|c|c|c|}
\hline No & Item & variables & Number of response & percentage $(\%)$ \\
\hline \multirow[t]{4}{*}{8} & \multirow{4}{*}{$\begin{array}{l}\text { How often do the teachers correct } \\
\text { your mistake while you are } \\
\text { speaking skill your tasks? }\end{array}$} & Some times & 14 & $45.16 \%$ \\
\hline & & always & 12 & $38.70 \%$ \\
\hline & & rarely & 3 & $9.67 \%$ \\
\hline & & Not all & 2 & $6.67 \%$ \\
\hline Total & & & 31 & $100 \%$ \\
\hline
\end{tabular}

As table 8 indicated 14(45.16\%), 12(38.70\%) of respondents responded that students have sometimes and always respectively, as teachers correct mistake while speaking skill their tasks. But 3(9.67\%), 2(6.67\%) of respondents responded that rarely and not all respectively. This implies that mistake does not affect their speaking tasks. As the data shows majority of the students have the teachers correct their mistake while speaking skill tasks.

Table 9: the students response evaluate speaking skill.

\begin{tabular}{|l|l|l|l|l|}
\hline \multirow{2}{*}{ No } & Item & variables & Numbers of respondents & percentage $(\%)$ \\
\hline \multirow{2}{*}{$\begin{array}{l}\text { Can you evaluate speaking } \\
\text { skill }\end{array}$} & Very bad & 12 & $45.16 \%$ \\
\cline { 3 - 5 } & & Bad & 10 & $32.25 \%$ \\
\cline { 3 - 5 } & & Good & 5 & $16.12 \%$ \\
\cline { 3 - 5 } & & Very good & 4 & $12.90 \%$ \\
\hline Total & & & 31 & $100 \%$ \\
\hline
\end{tabular}

As table 9: depicts 12(45.16\%), 10(32.25\%) respondents responded that very bad and bad respectively. According to the students responded that their does not evaluate speaking skill in the classroom. But 5(16.12\%), $4(12.90 \%)$ respondents responded that their students do not evaluate speaking skill. As the data shows, majority of the students have lack of evaluate speaking skill.

Table 
Table 10:the students response lack of enough opportunity to practice speaking affects in the class their speaking skill.

\begin{tabular}{|l|l|l|l|l|}
\hline No & Item & variables & Number of respondents & percentage(\%) \\
\hline 10 & \multirow{2}{*}{$\begin{array}{l}\text { Lack of enough } \\
\text { opportunity to practice } \\
\text { speaking affects in the } \\
\text { class my speaking skill. }\end{array}$} & Strongly agree & 17 & $56.667 \%$ \\
\cline { 3 - 5 } & & agree & 8 & $25.81 \%$ \\
\cline { 3 - 5 } & & disagree & 4 & $13.33 \%$ \\
\cline { 3 - 5 } & & Strongly disagree & 1 & $3.33 \%$ \\
\hline Total & & & 31 & $100 \%$ \\
\hline
\end{tabular}

As table 10 indicates, $17(56.667 \%), 8(25.81 \%)$ of respondents responded that students have strongly agree respectively. According to the students response lack of enough opportunity to practice speaking affects their class. But $4(13.33 \%), 1(3.33 \%)$ of respondents answered disagree and strongly disagree respectively. So this implies that lack of enough opportunity to practice speaking English with my classmates affects my speaking skill.

\subsection{Analysis and Interpretation of students open- ended question}

1. What are the major problem that you have faced while you are speaking English in class?

For this states their number of students responded that they have faced like, lack of having back ground knowledge are the major problems fright to speak in English. Not only this problem but also respondents explain the following as a major factors that affects their speaking skill;

$$
\begin{array}{ll}
\checkmark & \text { Influence of mother tongue } \\
\checkmark & \text { Lack of speaking habit in English } \\
\checkmark & \text { Fear of making mistake } \\
\checkmark & \text { Negative attitude to English language speaking }
\end{array}
$$

2. what do you do to overcome the above problem?

As respondents replied on this question, the following are their strategies to improve speaking skill;

$>$ Practice speaking skill English frequently

$>$ Watching television and listening to radio of English program

$>$ Reading different materials like newspaper, magazine, short story, dictionary

3.What you should be done to improve your speaking skill in class room?

For this question respondents responded that participate in different group activity, knowing high vocabulary word and debate in different topic.

\subsection{The Interview response from the Instructor}

1. What factors do you think affect your students speaking skill?

According to the instructor's response he responded that different factors that affect students speaking skill. These include; lack of experience or practice in speaking, shyness ,being afraid of making mistakes, undermining the value of English language, lack of practice and audio and video materials used to teach speaking skill.

2. What do you do think the ways to improve your students speaking practice in English classroom?

As the instructor said that making practice without shyness or being afraid of making mistakes, understanding the value of having good English speaking skills, making students to communicate each other both inside and outside classroom and using technology that enhance speaking skills.

3. How is the students' effort in learning speaking?

As Instructor said on this questions that most of the time the students do not do much effort the improve their speaking skill .They also do not give much emphasis for speaking skills as other skills.

\subsection{Result of classroom observation}

As the researcher observed, the students participation in the class students do not actively participating in the classroom discussion. when the teachers teaches in class, and ask some questions the students .But, students are do not participate rather they keep silent. From this they do not pay attention to the language to improve their speaking skill. Because students during the presentation time they are not present perfectly. Due to lack of confidence, lack of pronunciation and grammar problem are causes of students to have less speaking skill. 


\section{SUMMARY CONCLUSION AND RECOMMENDATION}

\subsection{Summary}

This study is about an assessment of factors that affect speaking skill of first year English major students at Debre markos university. To get adequate and relevant data for study, the researcher uses different data gathering methods: questionnaire and classroom observation. The researcher used census method to select the respondents and all students found in the class for questionnaires. Finally, the data were analyzed and interpreted quantitatively and qualitatively methods of data analysis.Generally, the main finding of this study from the data analysis and interpretation are:

- $\quad$ Lack of organizing ideas and self confidence

- $\quad$ Poor word power and unable to pronounce words

- Frustrating on preference of mother tongue

- $\quad$ Lack of motivation

- Lack of vocabulary

\section{2 conclusion}

As we have seen in the data interpretation and analysis, this study has tried to find out the major factors that affect students speaking skill. According, shortage of vocabulary and unable to pronounce words correctly are some of the obstacles. And doing speaking practice has great contribution for the improvement of speaking skill. students may lose interest during class room interesting in English language, because lack of confidence and organizing ideas. organizing idea and confidence play great role deliver speech accurately and fluently.

\subsection{Recommendation}

based on the finding obtained, the researcher would like to suggest the following:

- students should practice way of pronouncing words through different techniques like, listening English language media, using dictionary to know the exact sound of the word.

- students must develop grammar knowledge -they need to avoid frustration while they speak having a full confidence.

-students should be given a chance of expressing themselves in any situation such as drama, dialogues, etc.

-Teachers should encourage students to speak in the class room and out of the class room.

\section{REFERENCE}

Beleng.(2000). Teaching English to speaker of the other language. United kingdom: Cambridge university.

Brown H.(1994).Teaching principles of an interactive approach to language pedagogy :Englewood cliff njprentile.

F. verdure(2000). The challenges of affective speaking eleven edition. University of Cincinnati united state of America.

Homer,(1983).the practice of English language teaching. Cambridge university press.

Joyce.(1997)focus on speaking Sydney. National center for English language teaching and language and research. Lind say (knight2006). Learning teaching English: oxford university press.

M.jesa(2008).Efficient teaching. Cal cut India.

sigh k. Teaching of English. Chinos mai university.

http://www.com.Area.deg/mec/pt/garmmatical. What is speaking?

http://www.com.sir.org/lingqualink/language learning speaking skill

$\mathrm{http}: / /$ www.com.English with galin Blongspot.com/problem in speaking.

http://www.ncirc.org/strategy for developing speaking skill. 